\title{
Biochar-based organic fertilizer application rates for Tetrastigma hemsleyanum planted under Moso bamboo
}

\author{
Xiaoping Zhang ${ }^{1,2} \cdot$ Guibin Gao ${ }^{1,2,3} \cdot$ Zhizhuang $\mathrm{Wu}^{1,2} \cdot$ Xing Wen ${ }^{1,2,3} \cdot$ \\ Fangyuan Bian $^{1,2} \cdot$ Chuanbao Yang ${ }^{1,2}$
}

Received: 11 April 2018/Accepted: 25 February 2019/Published online: 9 May 2019

(C) The Author(s) 2019

\begin{abstract}
The under-forest economy has received increased attention in China. However, little is known about the effects of co-composted biochar on soil and plant biomass in under-forest planting systems. In this study, plant biomass, soil nutrient levels, and bacterial communities were evaluated after application of biochar-based organic fertilizer (BOF, derived from co-composted biochar-compost) at varying rates to soils supporting $\mathrm{Te}$ trastigma hemsleyanum Diels \& Gilg planted under a Moso bamboo (Phyllostachys edulis) forest. BOF treatment increased the biomass of $T$. hemsleyanum. Compared with the control, BOF application significantly increased soil $\mathrm{pH}$ and organic carbon (SOC). The high-throughput sequencing results showed significant differences in the
\end{abstract}

Project funding: The work was supported by the Cooperation Projects Between Provincial Government and Scientific Research Institutes for Forestry Science and Technology in Zhejiang Province (Grant No. 2017SY02).

The online version is available at http://www.springerlink.com

Corresponding editor: Tao $\mathrm{Xu}$

Zhizhuang Wu

wzzcaf@126.com

1 Key Laboratory of Resources and Utilization of Bamboo of State Forestry Administration, China National Bamboo Research Center, Hangzhou 310012, Zhejiang, People's Republic of China

2 Key Laboratory of High Efficient Processing of Bamboo of Zhejiang Province, Hangzhou 310012, Zhejiang, People's Republic of China

3 National Long-term Observation and Research Station for Forest Ecosystem in Hangzhou-Jiaxing-Huzhou Plain, Hangzhou 310012, Zhejiang, People's Republic of China
Bacteroidetes, Verrucomicrobia, Chlorofexi, and OD1 phyla among all groups. At the genus level, the control group was characterized by a preponderance of Conexibacter. Rhodanobacter was enriched in soils with a $3 \%$ BOF application and Steroidobacter and Spirochaeta were the most prominent phyla in the 5\% BOF group. There was no biomarker selected in the $1 \% \mathrm{BOF}$ group at the genus level. In conclusion, BOF application increased the biomass of T. hemsleyanum when intercropped under a Moso bamboo forest; this effect may be due to changes in the soil physicochemical properties and microbial communities after BOF application.

Keywords Co-composted biochar · Under-forest economy $\cdot$ Plant biomass $\cdot$ Soil microbiota

\section{Introduction}

Tetrastigma hemsleyanum Diels et Gilg, Vitaceae, is a herbaceous perennial climber species native to China. $T$. hemsleyanum is found in tropical to subtropical areas in Asia, mainly in the few provinces of south China, viz. Zhejiang, Jiangxi, Guangxi, and Hunan (Chinese Flora Commission 2007). The root tubers and whole herbs are used as raw materials in Chinese medicine for the treatment of high fever, infantile febrile convulsion, pneumonia, asthma, hepatitis, rheumatism, menstrual disorders, sore throat, and scrofula. Due to over-exploitation, environmental deterioration, and difficulties in cultivation (Dai et al. 2009), T. hemsleyanum has become an endangered species.

The under-forest economy is a sector of agroforestry, a green, low-carbon, three-dimensional, cyclic, and sustainable economic system (Miao et al. 2015). In recent years, 
the under-forest economy has received increased attention in China and is being vigorously developed (Chen et al. 2015). Research has indicated that establishing under-forest medicinal plant farming can protect rare medicinal plant resources, speed up construction and certification of standardized planting bases,and promote sustainable development of the medicinal plant industry (Du et al. 2014). Moso bamboo (Phyllostachys edulis) is an important plantation resource in southern China, covering an area of 4.43 million ha and accounting for $70 \%$ of the total area of Chinese bamboo forest (Song et al. 2011).It has been reported that $T$. hemsleyanum could be intercropped under bamboo forests ( $\mathrm{Wu}$ et al. 2015).

Biochar is a carbon-rich product from the pyrolysis of bio-wastes and its use as soil amendment provides multiple benefits, including improved soil fertility, crop productivity (Liu et al. 2013; Pandey et al. 2016; Gao et al. 2017), soil structure, water retention (Omondi et al. 2016), suppression of plant diseases (Rogovska et al. 2017), and stabilization of potentially toxic metals (Oustriere et al. 2017) and organic pollutants (Oustriere et al. 2017). Negative effects of biochar on crop yields have also been reported (Van Zwieten et al. 2010; Andrew et al. 2013; Borchard et al. 2014a). These effects include phytotoxicity and nutrient imbalance (Ding et al. 2010; Taghizadeh-Toosi et al. 2011; Borchard et al. 2014b). These limitations may be overcome by combining the application of biochar with compost (Steiner et al. 2010; Fischer and Glaser 2012). However, little is known regarding the effects of co-composted biochar on soil and plant biomass in under-forest planting systems.

In this study, biochar-based organic fertilizer (BOF), derived from the combination of biochar and compost, was applied to soils supporting T. hemsleyanum Diels \& Gilg planted under a Moso bamboo forest. The objectives of this study were to investigate the effects of different application rates of $\mathrm{BOF}$ on plant biomass, soil nutrient levels, and bacterial communities. To our knowledge, this is the first study to investigate these metrics after different BOF applications in under-forest intercropping systems.

\section{Materials and methods}

\section{Experimental site}

This study was carried out at Quanwang Township $\left(28^{\circ} 56^{\prime} \mathrm{N}, 118^{\circ} 55^{\prime} \mathrm{E}\right)$ in Qujiang District, Quzhou City, Zhejiang Province in southeast China. This region is a subtropical zone of humid monsoon climate with four distinct seasons. Annual rainfall is $1667 \mathrm{~mm}$, and average annual temperature is $17.3^{\circ} \mathrm{C}$. The lowest recorded temperature is $-10.4{ }^{\circ} \mathrm{C}$ and the highest is $40.5{ }^{\circ} \mathrm{C}$. The average annual frost-free period is 258 days and average cumulative annual daily sunshine is $1713 \mathrm{~h}$. The elevation of the site is $500-560 \mathrm{~m}$ a.s.l. The soil is medium thick yellow brown earth and is fertile.

\section{Experimental design}

Our BOF was produced by Zhejiang Raymond Agricultural Polytron Technologies Inc. (Hangzhou, Zhejiang). The BOF included nitrogen, $\mathrm{P}_{2} \mathrm{O}_{5}$, and $\mathrm{K}_{2} \mathrm{O}$ at rates of $6 \%$, $2.3 \%$, and $2.5 \%$, respectively. Organic matter content was greater than $40 \%$ and $\mathrm{pH}$ ranged from 5.8 to 6.0 .

The sample site had been a moso bamboo forest for many years, with an average canopy density of $80 \%$, average diameter of $9.8 \mathrm{~cm}$, and an average plant height of 14.2 m. T. hemsleyanum was intercropped in 2014, and in 2015, was cut to $10 \mathrm{~cm}$ long stems for cuttage cultivation. At that point, the $T$. hemsleyanum plantlets were obtained. In April 2016, we dug soil from the moso forest, placed it in non-woven bags of approximately $10 \mathrm{~L}$ capacity, and then mixed it with $0 \%$ (control), 1\%, 3\%, and 5\% BOF. Each group had three replicates, each replicate had ten bags, and each bag had two $T$. hemsleyanum plantlets. During the experiment, irrigation, grass and pest control were performed.

\section{Plant biomass}

We collected roots, stems, and leaves of the T. hemsleyanum plantlets at the close of the study for analyses. The roots, stems and leaves are henceforth called dry matter. The dry matter was dried in an oven at $105^{\circ} \mathrm{C}$ for $30 \mathrm{~min}$, and then the temperature was set to $70-80{ }^{\circ} \mathrm{C}$ to obtain a constant weight.

\section{Soil physicochemical analysis}

Soil samples from non-woven bags were analyzed for soil physicochemical properties and microbial communities in October 2016. Soil pH was determined with a glass electrode using a soil-to-water ratio of 1:2.5 (w/v). Determination of soil organic carbon (SOC) was performed by means of the $\mathrm{K}_{2} \mathrm{Cr}_{2} \mathrm{O}_{7}$ oxidation-reduction titration method. Determination of the soil total nitrogen (TN) was performed by the diffusion method using the forestry industry standard of China (LY/T 1228 - 1999). Available $\mathrm{P}$ (AP) was extracted using $0.5 \mathrm{~mol} \cdot \mathrm{L}^{-1} \mathrm{NaHCO}_{3}$ at $\mathrm{pH} 8.5$ (Olsen 1954) and measured using a colorimeter (UV2550; Shimadzu, Japan). Total phosphorus (TP) was measured by spectrophotometry after wet digestion with $\mathrm{HClO}_{4}-\mathrm{H}_{2} \mathrm{SO}_{4}$. 


\section{DNA extraction, PCR amplification and Illumina sequencing}

Soil bacterial DNA from each sample was extracted using a soil DNA Extraction Kit (Tiangen, Beijing, China) according to the manufacturer's instructions. The V3 and V4 regions were amplified using forward primers containing the sequence CCTACGGGNGGCWGCAG and reverse primers containing the sequence GACTACHVGGGTATCTAATCC. PCR was conducted in $20 \mu \mathrm{l}$ reactions with $1 \times$ reaction buffer (Takara, Dalian, China), $2 \mathrm{mM} \mathrm{Mg}^{2+}, 0.2 \mathrm{mM}$ dNTPs, $0.1 \mu \mathrm{M}$ of each primer, 1 U HotStarTaq polymerase (Takara, Dalian, China) and $2 \mu \mathrm{l}$ of template DNA. The cycling program was as follows: $95{ }^{\circ} \mathrm{C}$ for $2 \mathrm{~min}$; 35 cycles of $94{ }^{\circ} \mathrm{C}$ for $20 \mathrm{~s}, 55{ }^{\circ} \mathrm{C}$ for $40 \mathrm{~s}$, and $72{ }^{\circ} \mathrm{C}$ for $1 \mathrm{~min}$; and then $72{ }^{\circ} \mathrm{C}$ for $2 \mathrm{~min}$. To add specific tag sequences to each sample, the PCR reaction was performed in a total volume of $20 \mu \mathrm{L}$ containing $1 \times$ reaction buffer (NEB Q5TM), $0.3 \mathrm{mM}$ dNTPs, $0.25 \mu \mathrm{M}$ F primer, $0.25 \mu \mathrm{M}$ index primers, $1 \mathrm{U}$ Q5TM DNA polymerase (NEB) and $1 \mu$ of diluted template. The PCR conditions were as follows: an initial denaturation step at $98{ }^{\circ} \mathrm{C}$ for $30 \mathrm{~s}, 11$ cycles of denaturation at $98{ }^{\circ} \mathrm{C}$ for $10 \mathrm{~s}$, annealing at $65^{\circ} \mathrm{C}$ for $30 \mathrm{~s}$, extension at $72{ }^{\circ} \mathrm{C}$ for $30 \mathrm{~s}$, and a final extension step of $72{ }^{\circ} \mathrm{C}$ for $5 \mathrm{~min}$. PCR products were visualized and cleaned using gel electrophoresis and the QIAquick Gel Extraction Kit (Qiagen). The DNA concentration of each PCR product was quantified using a UV-Vis spectrophotometer (NanoDrop ND1000, USA) and then pooled in an equimolar manner. Next, generation of the sequencing library preparations and Illumina MiSeq sequencing were conducted at G-BIO Inc. (Hangzhou, China).

\section{S rRNA data processing}

PANDAseq (Masella et al. 2012) was used for quality filtering and the assembly of the two ends of each read into contigs, with parameters including a $400 \mathrm{bp}$ minimum and $500 \mathrm{bp}$ maximum. Chimeric reads were filtered using the "identity_chimeric_seqs.py" module of USEARCH (Edgar 2010) in QIIME v.1.9 (Caporaso et al. 2010). The chimerafiltered sequences from each sample were combined into one file using the QIIME script add_qiime_labels.py. Operational taxonomic units (OTUs) were picked based on 97\% identity using the open-reference OTU-picking workflow pipelines (Caporaso et al. 2010) and the UCLUST algorithm (Edgar 2010) against the Greengenes reference database (DeSantis et al. 2006) August 2013 release. OTUs with an abundance below $0.005 \%$ of the total number of sequences were discarded (Bokulich et al. 2013). Alpha diversity measurements were calculated using the alpha_rarefaction.py script in QIIME. Weighted and unweighted unifrac distances (Lozupone and Knight 2005) were calculated from the rarefied OTU table using the beta_diversity_through_plots.py script in QIIME.

\section{Statistical analysis}

The linear discriminant analysis (LDA) effect size (LEfSe) method was used (Segata et al. 2011) to compare the microbial composition of the BOF treatments and the control groups. The relative abundance of bacterial groups in samples from the BOF and control groups were compared using one-way ANOVA (Statistical Package Social Science, SPSS, version 19.0). The compare_alpha_diversity.py script was used to compare the alpha diversity (within sample diversity) metrics in the QIIME pipeline, which implements a nonparametric two-sample $t$ test with 999 Monte Carlo permutations. Beta diversity (between sample diversity) comparisons were completed using ANOSIM (compare_categories.py; QIIME). A p-value < 0.05 was considered statistically significant.

\section{Results}

\section{Plant biomass allocation}

Total biomass showed significant increase in plants grown under BOF treatments in the following order: $3 \%>1 \%>5 \%$ BOF (Fig. 1). For stem biomass (Fig. 1), significant increase was recorded in the $1 \% \mathrm{BOF}$ and $3 \%$ BOF treatments, but no difference was recorded between the 5\% BOF treatment and the control. All BOF treatments significantly increased leaf biomass $(3 \%>1 \%>5 \%$ BOF, Fig. 1). T. hemsleyanum exhibited no significant

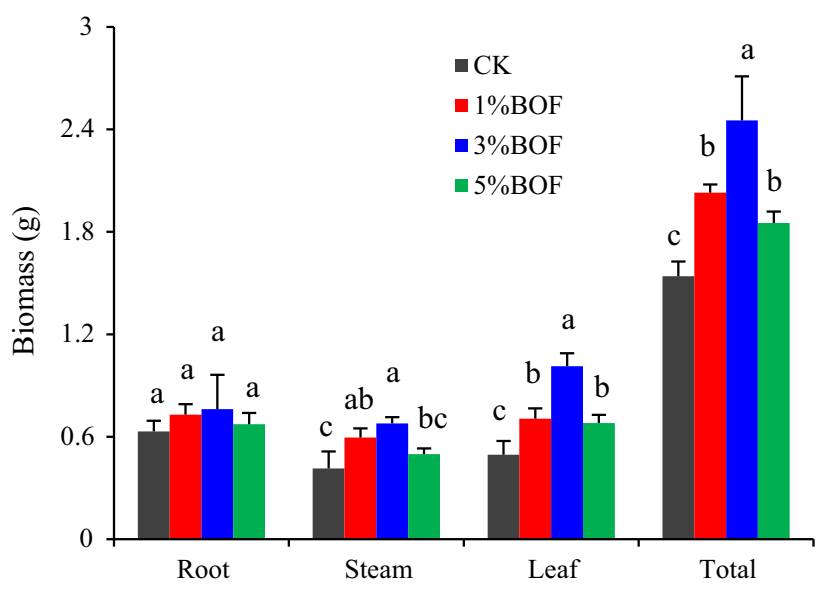

Fig. 1 Variation in plant biomass allocation in Tetrastigma hemsleyanum among the four treatments 
increase in plant root biomass in the presence of BOF (Fig. 1).

\section{Soil properties}

BOF treatments increased soil $\mathrm{pH}$ by $0.68-1.34$ compared with the control group (Table 1). There were significant differences in soil $\mathrm{pH}$ between the control (CK) and BOFtreated soils. SOC content increased by $22.03 \%, 14.39 \%$, and $43.73 \%(p<0.05)$ in BOF applications of $1 \%, 3 \%$, and $5 \%$, respectively. SOC content differed by BOF group and ranked in the following order: $5 \%>1 \%>3 \% \mathrm{BOF}$. TN content in the $1 \%$ and $5 \%$ BOF treatments was $18.46 \%$ and $32.82 \%$ higher $(p<0.05)$, respectively, than in the control. $\mathrm{C} / \mathrm{N}$ was similar in the control and BOF groups. Total phosphorus and available phosphorus were significantly higher in the 5\% BOF group and significantly lower in the $1 \%$ BOF group than in the control. There was no difference in total nitrogen, total phosphorus and available phosphorus between the $3 \%$ BOF and control groups.

\section{Sequencing data and taxonomic assignments}

A total of 262,296 sequences passed the quality check and were considered for further analysis. These sequences were classified to the genus level at a $97 \%$ sequence identity threshold.

A total of 10 phyla with an abundance $>0.5 \%$ were identified in the soil samples. Figure 2 shows the relative abundance of the community compositions (bacterial phylum and family) in the control and BOF-treated groups. The most abundant phylum in all soil samples was Proteobacteria, which accounted for approximately $41.83 \%$ of all sequences, followed by Acidobacteria (16.39\%), Actinobacteria (10.69\%), Chloroflexi (7.59\%), Planctomycetes (4.06\%), Bacteroidetes (4.20\%), Verrucomicrobia (4.30\%), OD1 (3.81\%), Gemmatimonadetes (1.48\%), TM7 (0.94\%), and Firmicutes (0.69\%) (Fig. 2a). Among the 23 known families detected in the present study with an abundance $>0.5 \%$, the most commonly identified families were Xanthomonadaceae (19.87\%), Acidobacteriaceae (11.48\%), Sinobacteraceae (3.21\%), Thermogemmatisporaceae
(2.47\%), Rhodospirillaceae (2.43\%), Acetobacteraceae $(2.22 \%)$, Chitinophagaceae $(2.07 \%)$, Solibacteraceae (1.51\%), auto67_4 W (1.12\%), Comamonadaceae (1.09\%), Hyphomicrobiaceae (1.03\%), Pirellulaceae $(0.91 \%)$, Alcaligenaceae $(0.86 \%)$, Caulobacteraceae $(0.73 \%)$, Streptomycetaceae $(0.71 \%)$, Gemmataceae $(0.69 \%)$, Opitutaceae $(0.69 \%)$, Koribacteraceae $(0.64 \%)$, Isosphaeraceae $(0.63 \%)$, Mycobacteriaceae $(0.61 \%)$, Sphingobacteriaceae $(0.61 \%)$, Cytophagaceae $(0.60 \%)$, and Conexibacteraceae $(0.57 \%)$ (Fig. 2b).

\section{Bacterial alpha-diversity and beta-diversity}

Alpha and beta diversity analysis was performed, and plots were created specifying a sampling depth of 17,189 . Rarefaction curve analysis suggested that the sequencing depth in this study was adequate (Fig. 3). There were no significant differences in Shannon, Chao1, Faith's phylogenetic diversity, or observed species indexes (Table 2).

A comparison of the similar communities found in each sample is shown in Fig. 2. Communities differed by treatment when analyzed using the weighted Unifrac matrix (ANOSIM, $p=0.001$ ) and unweighted Unifrac matrix (ANOSIM, $p=0.001$ ) (Fig. 4).

\section{Microbial differential abundance}

Microbial abundance differed by BOF treatment for phyla Bacteroidetes, Verrucomicrobia, Chlorofexi, and OD1 (Fig. 5). Compared with the control, the $3 \%$ BOF treatment yielded significantly higher abundance of sequences affiliated with Verrucomicrobia and Bacteroidetes. The 3\% BOF treatment had a decreased abundance of Verrucomicrobia, Bacteroidetes, and OD1, relative to the $5 \% \mathrm{BOF}$ treatment. No difference was observed between the $3 \%$ BOF and $1 \%$ BOF groups.

To further detect major differences between the BOFtreated and control groups, the LEfSe method was used to analyse the metagenomic data of bacterial taxa. There were 47 differentially abundant taxonomic clades with an LDA score higher than 3.5: 15, 3, 7, and 22 clades representing the control, $1 \% \mathrm{BOF}, 3 \% \mathrm{BOF}$, and $5 \% \mathrm{BOF}$ groups,

Table 1 Selected soil properties from the control and BOF treatments

\begin{tabular}{lllllll}
\hline Treatment & $\mathrm{pH}$ & $\mathrm{SOC}\left(\mathrm{g} \mathrm{kg}^{-1}\right)$ & $\mathrm{TN}\left(\mathrm{g} \mathrm{kg}^{-1}\right)$ & $\mathrm{C} / \mathrm{N}$ & $\mathrm{TP}\left(\mathrm{g} \mathrm{kg}^{-1}\right)$ & $\mathrm{AP}\left(\mathrm{mg} \mathrm{kg}^{-1}\right)$ \\
\hline $\mathrm{CK}$ & $4.22 \pm 0.13 \mathrm{c}$ & $20.15 \pm 0.72 \mathrm{~d}$ & $1.95 \pm 0.09 \mathrm{c}$ & $10.34 \pm 0.11 \mathrm{a}$ & $1.20 \pm 0.05 \mathrm{~b}$ & $185.94 \pm 5.56 \mathrm{~b}$ \\
$1 \%$ BOF & $4.90 \pm 0.24 \mathrm{~b}$ & $24.59 \pm 0.76 \mathrm{~b}$ & $2.31 \pm 0.14 \mathrm{ab}$ & $10.65 \pm 0.32 \mathrm{a}$ & $1.02 \pm 0.09 \mathrm{c}$ & $137.38 \pm 2.05 \mathrm{c}$ \\
$3 \%$ BOF & $4.91 \pm 0.55 \mathrm{ab}$ & $23.05 \pm 0.46 \mathrm{c}$ & $2.04 \pm 0.29 \mathrm{~b}$ & $11.41 \pm 0.41 \mathrm{a}$ & $1.22 \pm 0.07 \mathrm{~b}$ & $180.95 \pm 2.56 \mathrm{~b}$ \\
$5 \%$ BOF & $5.56 \pm 0.33 \mathrm{a}$ & $28.96 \pm 0.26 \mathrm{a}$ & $2.59 \pm 0.11 \mathrm{a}$ & $11.19 \pm 0.38 \mathrm{a}$ & $1.57 \pm 0.04 \mathrm{a}$ & $225.21 \pm 3.07 \mathrm{a}$ \\
\hline
\end{tabular}


Fig. 2 The soil microbial composition in the control and BOF groups at the phylum (a) and family (b) levels
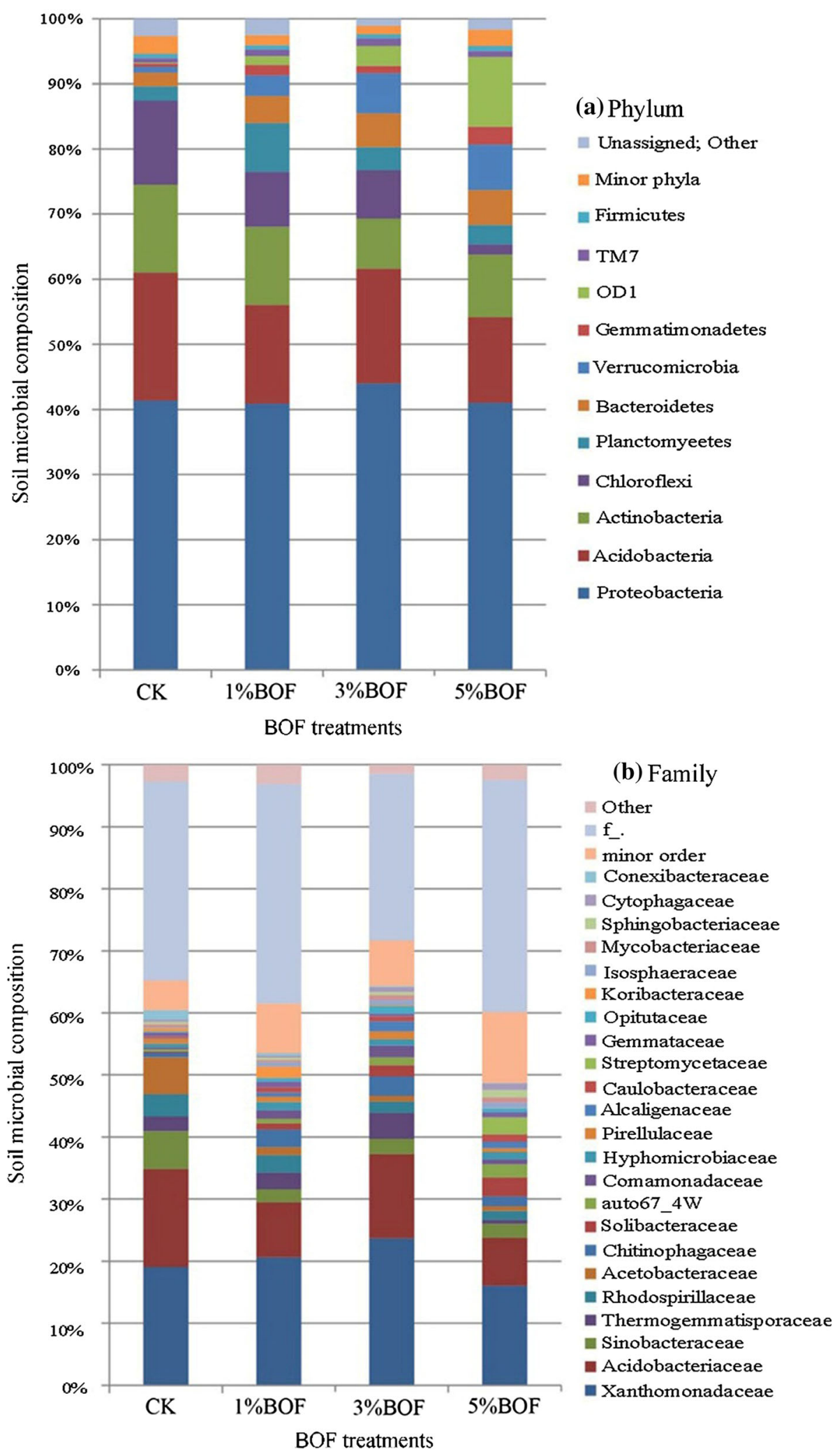

respectively (Fig. 5). At the genus level, Steroidobacter and Spirochaeta were the most prominent phyla in the 5\% BOF group, and Rhodanobacter was enriched in soils with a 3\% BOF application. The control was characterized by a preponderance of Conexibacter. There was no biomarker associated with the $1 \%$ BOF group at the genus level. 


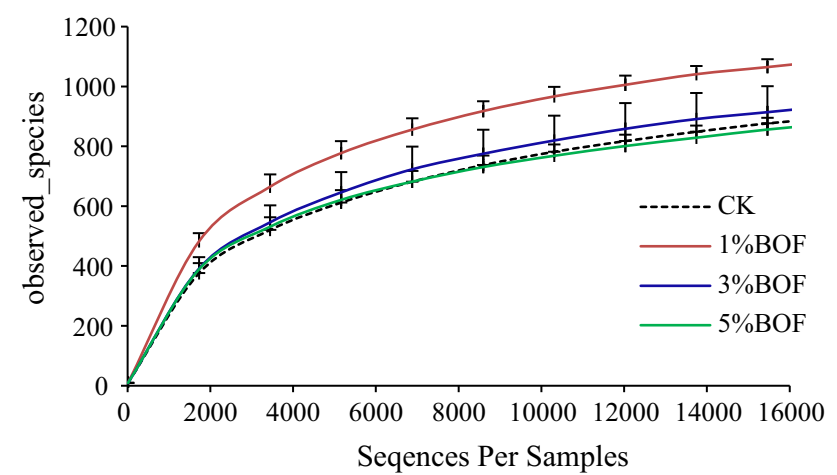

Fig. 3 Rarefied plot for the relationship between the number of sequences per sample ( $\mathrm{x}$ axis) and the number of observed species ( $\mathrm{y}$ axis)

\section{Discussion}

Our results show that soil, plants, and bacterial communities were influenced by the application of BOF. BOF significantly increased $T$. hemsleyanum total biomass. This is consistent with previous studies demonstrating that the same application of BOF significantly increased the growth of Pistacia chinensis Bunge (Wu et al. 2015). Kammann et al. (2015) showed that plant growth exhibited up to a fivefold increase with composted biochar compared to untreated biochar, and up to a threefold increase compared to the control. Luo et al. (2017) reported that biocharcompost addition at a lower rate (e.g., 1.5\%) promoted the growth of Sesbania, but inhibited its growth at rates of 5 and $10 \%$.

Both biochar and compost have been shown to improve soil properties (Zhang et al. 2012; Abujabhah et al. 2016; Agegnehu et al. 2017), although the effects are dependent on factors such as soil type and the amount/characteristics of the amendment. In our study, BOF application increased soil pH. Schulz et al. (2013) showed that composted biochar had no significant effect on $\mathrm{pH}$ in sandy substrate. This result may be explained by the fact that the composted biochar showed $\mathrm{pH}$ values similar to the $\mathrm{pH}$ values of the soil substrate. Therefore, the increased soil $\mathrm{pH}$ after BOF application may be due to the higher $\mathrm{pH}$ of the BOF than that of the soil substrate. Bass et al. (2016) reported that no difference was observed between the $\mathrm{pH}$ of the control and the compost-biochar treatments, probably due to low biochar application rates. We found that BOF application significantly increased the SOC content. Previous studies reported that total SOC significantly increased due to the application of various types of biochar (Kimetu and Lehmann 2010; Xie et al. 2013; Angst et al. 2014). Agegnehu et al. (2016) reported that SOC and TN increased by 14-29\% and 59-117\%, respectively, compared to the initial nutrient content of the soil. Glisczynski et al. (2016) showed that biochar-compost substrate applications containing $15 \%$ and $30 \%$ of biochar significantly increased SOC stocks.
Table 2 Analysis of soil microbial $\alpha$ - diversity in the different treatments

\begin{tabular}{lllcc}
\hline Treatment & shannon & chao1 & observed_species & PD_whole_tree \\
\hline CK & $7.26 \pm 0.48$ & $1083.77 \pm 100.11$ & $901 \pm 149$ & $49.16 \pm 5.96$ \\
$1 \%$ BOF & $7.83 \pm 0.39$ & $1237.09 \pm 30.57$ & $1094 \pm 27$ & $57.04 \pm 0.82$ \\
$3 \%$ BOF & $7.19 \pm 0.32$ & $1106.00 \pm 155.89$ & $936 \pm 120$ & $50.76 \pm 5.39$ \\
$5 \%$ BOF & $7.42 \pm 0.42$ & $1074.01 \pm 41.95$ & $876 \pm 54$ & $48.37 \pm 1.57$ \\
\hline
\end{tabular}

$\mathrm{CK} \square 1 \% \mathrm{BOF}$

$3 \% \mathrm{BOF}$

$5 \%$ BOF

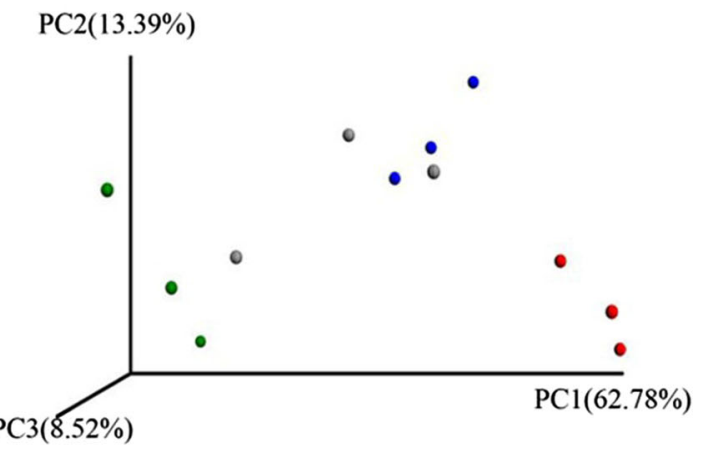

(a) Unweighted uniFrac

(b) Weighted uniFrac

Fig. 4 PcoA analysis based on Unweighted and Weighted UnFric in the different treatments 

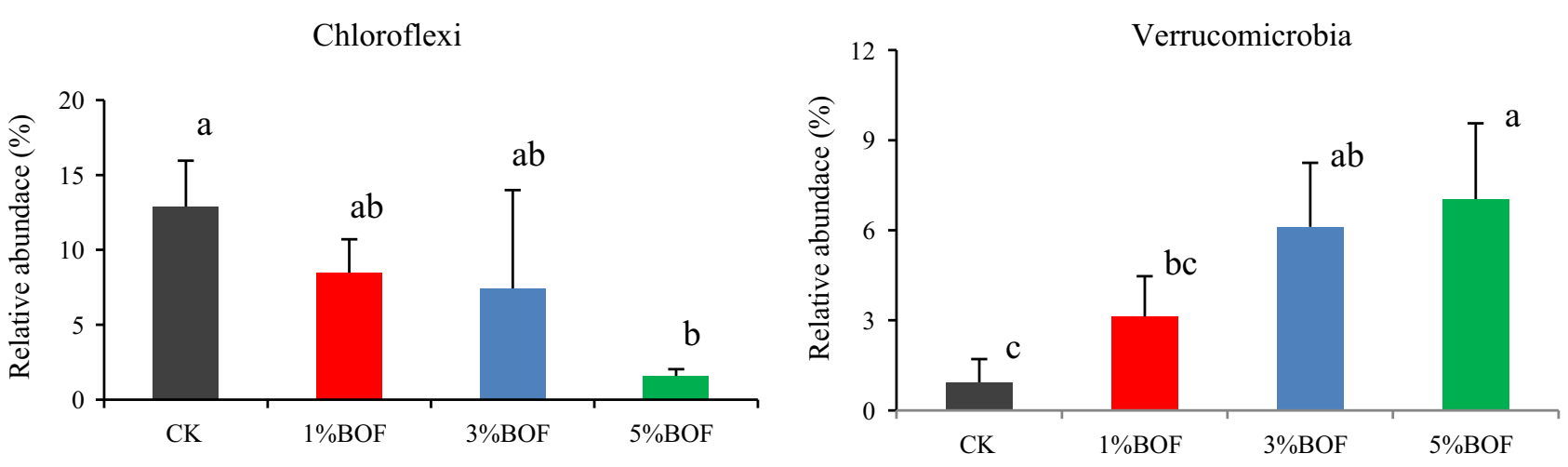

Bacteroidetes
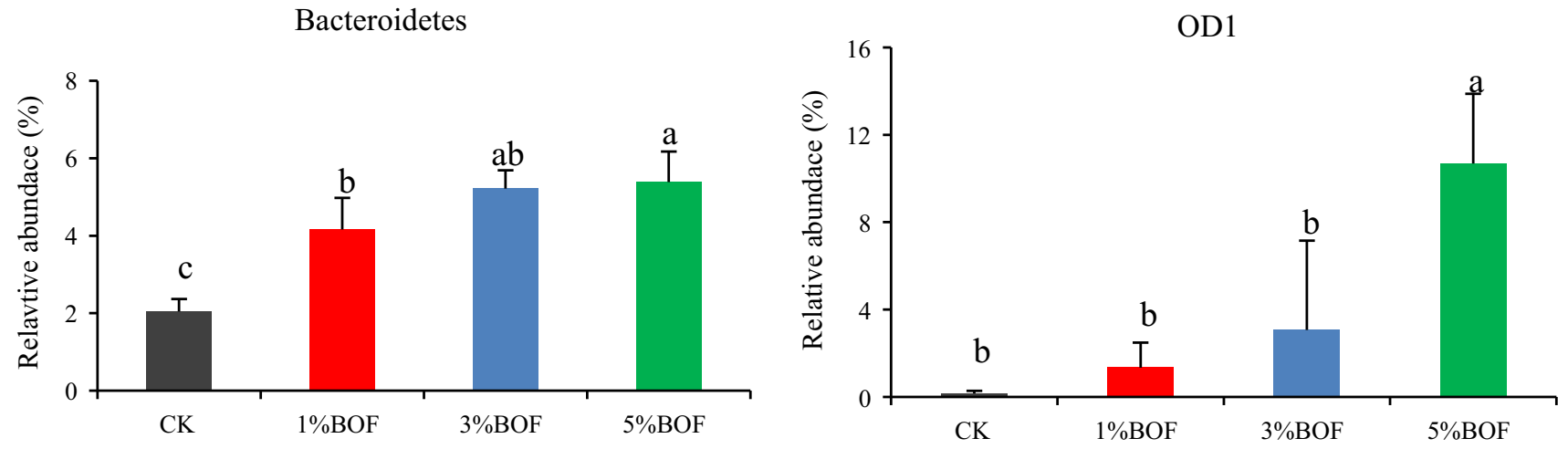

Fig. 5 Differences in phyla of the soil microbes in the four treatments

Soil bacterial diversity is considered to be critical for the integrity, function, and long-term sustainability of soil ecosystems (Kennedy and Smith 1995). Moreover, greater biodiversity in the soil can lead to a more stable ecosystem and enhance the combination of vital microbial functions and processes (Chaer et al. 2009). Loss of microbial diversity is the general consequence of long-term chemical fertilization. The return of crop residues can mitigate the negative effects of chemical fertilization on bacterial diversity (Ramirez et al. 2010; Sun et al. 2015). In our study, no difference was observed in the bacterial richness and diversity between the BOF and control treatments, possibly due to the short-term BOF application of only 6 months.

High-throughput sequencing results showed significant increases in abundances of microbes of the phyla Bacteroidetes, Verrucomicrobia, Chlorofexi, and OD1 for all BOF treatments. Bacteroidetes preferentially consume soil organic $\mathrm{C}$, have high nutrient requirements, and are more abundant when biogenic resources increase (Fierer et al. 2007). Chloroflexi and Acidobacteria are slow-growing bacteria (Davis et al. 2011) and generally prefer an oligotrophic environment (Hallam et al. 2004; Fierer et al. 2012). Representatives of the phylum Acidobacteria are typically abundant in conditions of low nutrient status due to their higher substrate affinities (Fierer et al. 2007). In our study, the relative abundance of Bacteroidetes increased significantly in BOF treatments compared to the control, and the abundance of Acidobacteria and Chloroflexi declined. These results indicate that the soil favoured copiotrophs over oligotrophs following BOF application. To the best of our knowledge, only one prior study used cultures isolated from soils to document the capacity of Verrucomicrobia to degrade polysaccharides (Chin et al. 1999). OD1 has mainly been detected in sulphur-rich, anoxic environments (Elshahed et al. 2005; Briée et al. 2007; Barberán and Casamayor 2011), and the partial genome revealed genes known only from anaerobic or facultative anaerobic microorganisms with genomic organization similar to that of methanotrophic Archaea (Elshahed et al. 2005) that are found in anoxic marine sediments (Hallam et al. 2004).

The LEfSe results showed that the genus Conexibacter was the most differentially abundant taxon in the control soil. Conexibacter are strictly aerobic, can reduce nitrate to nitrite, and might function in carbon cycling in soil ecosystems (Monciardini et al. 2003; Pukall et al. 2010; Seki et al. 2012). Our 3\% BOF application significantly increased the abundance of genus Rhodanobacter. Members of the genus Rhodanobacter are Gram-negative, rodshaped and aerobic, with most strains being catalase- and oxidase-positive (Madhaiyan et al. 2014). Steroidobacter and Spirochaeta were significantly influenced by the 5\% BOF application. The genus Spirochaeta was found to be 
positively correlated with the removal of CIP (Huang et al. 2017), secreted seven glycoside hydrolases for the degradation of plant biomass (Schiefner et al. 2016), and was a dominating bacterium for hydrolysis of lignocelluloses (Pandit et al. 2016). Some Steroidobacter spp. are strictly aerobic and have soil catalase activity (Sakai et al. 2014).

In conclusion, T. hemsleyanum biomass was increased by BOF application because (1) soil $\mathrm{pH}$ and SOC increased significantly after BOF application and (2) soil bacterial communities were increased by BOF application, and the responses differed among phyla and/or genera.

Open Access This article is distributed under the terms of the Creative Commons Attribution 4.0 International License (http://crea tivecommons.org/licenses/by/4.0/), which permits unrestricted use, distribution, and reproduction in any medium, provided you give appropriate credit to the original author(s) and the source, provide a link to the Creative Commons license, and indicate if changes were made.

\section{References}

Abujabhah IS, Bound SA, Doyle R, Bowman JP (2016) Effects of biochar and compost amendments on soil physico-chemical properties and the total community within a temperate agricultural soil. Appl Soil Ecol 98:243-253

Agegnehu G, Bass AM, Nelson PN, Bird MI (2016) Benefits of biochar, compost and biochar-compost for soil quality, maize yield and greenhouse gas emissions in a tropical agricultural soil. Sci Total Environ 543:295-306

Agegnehu G, Srivastava AK, Bird MI (2017) The role of biochar and biochar-compost in improving soil quality and crop performance: a review. Appl Soil Ecol 119:156-170

Andrew CD, Samuel A, Simon J, Margaret ST (2013) Heterogeneous global crop yield response to biochar: a meta-regression analysis. Environ Res Lett 8:044049

Angst TE, Six J, Reay DS, Sohi SP (2014) Impact of pine chip biochar on trace greenhouse gas emissions and soil nutrient dynamics in an annual ryegrass system in California. Agric Ecosyst Environ 191:17-26

Barberán A, Casamayor EO (2011) Euxinic freshwater hypolimnia promote bacterial endemicity in continental areas. Microb Ecol 61:465-472

Bass AM, Bird MI, Kay G, Muirhead B (2016) Soil properties, greenhouse gas emissions and crop yield under compost, biochar and co-composted biochar in two tropical agronomic systems. Sci Total Environ 550:459-470

Bokulich NA, Subramanian S, Faith JJ, Gevers D, Gordon JI, Knight R, Mills DA, Caporaso JG (2013) Quality-filtering vastly improves diversity estimates from Illumina amplicon sequencing. Nat Methods 10:57-59

Borchard N, Siemens J, Ladd B, Möller A, Amelung W (2014a) Application of biochars to sandy and silty soil failed to increase maize yield under common agricultural practice. Soil Tillage Res 144:184-194

Borchard N, Spokas K, Prost K, Siemens J (2014b) Greenhouse gas production in mixtures of soil with composted and noncomposted biochars is governed by char-associated organic compounds. J Environ Qual 43:971-979
Briée C, Moreira D, López-García P (2007) Archaeal and bacterial community composition of sediment and plankton from a suboxic freshwater pond. Res Microbiol 158:213-227

Caporaso JG, Kuczynski J, Stombaugh J, Bittinger K, Bushman FD, Costello EK, Fierer N, Pena AG, Goodrich JK, Gordon JI, Huttley GA, Kelley ST, Knights D, Koenig JE, Ley RE, Lozupone CA, McDonald D, Muegge BD, Pirrung M, Reeder J, Sevinsky JR, Turnbaugh PJ, Walters WA, Widmann J, Yatsunenko T, Zaneveld J, Knight R (2010) QIIME allows analysis of high-throughput community sequencing data. Nat Methods 7:335-336

Chaer G, Fernandes M, Myrold D, Bottomley P (2009) Comparative resistance and resilience of soil microbial communities and enzyme activities in adjacent native forest and agricultural soils. Microb Ecol 58:414-424

Chen J, Zhang HO, Wu QT (2015) Study on the development of under-forest economy in Guangdong mountain areas. Asian Agricultural Research 7(4):45-50

Chin KJ, Hahn D, Hengstmann U, Liesack W, Janssen PH (1999) Characterization and identification of numerically abundant culturable bacteria from the anoxic bulk soil of rice paddy microcosms. Appl Environ Microbiol 65:5042-5049

Dai YJ, Shen ZG, Liu Y, Wang LL, Hannaway D, Lu HF (2009) Effects of shade treatments on the photosynthetic capacity, chlorophyll fluorescence, and chlorophyll content of Tetrastigma hemsleyanum Diels et Gilg. Environ Exp Bot 65:177-182

Davis KER, Sangwan P, Janssen PH (2011) Acidobacteria, Rubrobacteridae and Chloroflexi are abundant among very slow-growing and mini-colony-forming soil bacteria. Environ Microbiol 13:798-805

DeSantis TZ, Hugenholtz P, Larsen N, Rojas M, Brodie EL, Keller K, Huber T, Dalevi D, Hu P, Andersen GL (2006) Greengenes, a Chimera-checked 16S rRNA gene database and workbench compatible with ARB. Appl Environ Microbiol 72:5069-5072

Ding Y, Liu YX, Wu WX, Shi DZ, Yang M, Zhong ZK (2010) Evaluation of biochar effects on nitrogen retention and leaching in multi-layered soil columns. Water Air Soil Pollut 213:47-55

Du RJ, Qu YJ, Jin H, Jiang HB, Du YC, Zhou DY, Jing FU, Shi P (2014) Interplanting patterns of cash crops under forest. Asian Agric Res 06:72-74

Edgar RC (2010) Search and clustering orders of magnitude faster than BLAST. Bioinformatics 26:2460-2461

Elshahed MS, Najar FZ, Aycock M, Qu C, Roe BA, Krumholz LR (2005) Metagenomic analysis of the microbial community at Zodletone Spring (Oklahoma): insights into the genome of a member of the novel candidate division OD1. Appl Environ Microbiol 71:7598-7602

Fierer N, Bradford MA, Jackson RB (2007) Toward an ecological classification of soil bacteria. Ecology 88:1354-1364

Fierer N, Lauber CL, Ramirez KS, Zaneveld J, Bradford MA, Knight R (2012) Comparative metagenomic, phylogenetic and physiological analyses of soil microbial communities across nitrogen gradients. ISME J 6:1007-1017

Fischer D, Glaser B (2012) Synergisms between compost and biochar for sustainable soil amelioration. In: Management of Organic Waste. InTech. pp 167 - 198 https://doi.org/10.5772/31200

Gao S, Hoffman-Krull K, DeLuca TH (2017) Soil biochemical properties and crop productivity following application of locally produced biochar at organic farms on Waldron Island, WA. Biogeochemistry 136:31-46

Glisczynski Fv, Pude R, Amelung W, Sandhage-Hofmann A (2016) Biochar-compost substrates in short-rotation coppice: effects on soil and trees in a three-year field experiment. J Plant Nutr Soil Sci 179:574-583

Hallam SJ, Putnam N, Preston CM, Detter JC, Rokhsar D, Richardson PM, DeLong EF (2004) Reverse methanogenesis: testing the 
hypothesis with environmental genomics. Science 305:1457-1462

Huang XP, Mo CH, Yu J, Zhao HM, Meng C, Li YW, Li H, Cai QY, Wong MH (2017) Variations in microbial community and ciprofloxacin removal in rhizospheric soils between two cultivars of Brassica parachinensis L. Sci Total Environ 603-604:66-76

Kammann CI, Schmidt HP, Messerschmidt N, Linsel S, Steffens D, Muller C, Koyro HW, Conte P, Joseph S (2015) Plant growth improvement mediated by nitrate capture in co-composted biochar. Sci Rep 5:11080

Kennedy AC, Smith KL (1995) Soil microbial diversity and the sustainability of agricultural soils. In: Collins HP, Robertson GP, Klug MJ (eds) The significance and regulation of soil biodiversity: proceedings of the international symposium on soil biodiversity, held at Michigan State University, East Lansing, May 3-6, 1993. Springer Netherlands, Dordrecht, pp $75-86$

Kimetu JM, Lehmann J (2010) Stability and stabilisation of biochar and green manure in soil with different organic carbon contents. Soil Res 48:577-585

Liu XY, Zhang AF, Ji CY, Joseph S, Bian RJ, Li LQ, Pan GX, PazFerreiro J (2013) Biochar's effect on crop productivity and the dependence on experimental conditions-a meta-analysis of literature data. Plant Soil 373:583-594

Lozupone C, Knight R (2005) UniFrac: a new phylogenetic method for comparing microbial communities. Appl Environ Microbiol $71: 8228-8235$

Luo XX, Liu GC, Xia Y, Chen L, Jiang ZX, Zheng H, Wang ZY (2017) Use of biochar-compost to improve properties and productivity of the degraded coastal soil in the Yellow River Delta, China. J Soils Sed 17:780-789

Madhaiyan M, Poonguzhali S, Saravanan VS, Kwon SW (2014) Rhodanobacter glycinis sp. nov., a yellow-pigmented gammaproteobacterium isolated from the rhizoplane of fieldgrown soybean. Int J Syst Evol Microbiol 64:2023-2028

Masella AP, Bartram AK, Truszkowski JM, Brown DG, Neufeld JD (2012) PANDAseq: paired-end assembler for illumina sequences. BMC Bioinformatics 13:31

Miao Y, Zhou Y, Yang C, Sun Z (2015) Developmental status and suggestions of under-forest economy in China. Forest Eng 31(5):35-39

Monciardini P, Cavaletti L, Schumann P, Rohde M, Donadio S (2003) Conexibacter woesei gen. nov., sp. nov., a novel representative of a deep evolutionary line of descent within the class Actinobacteria. Int J Syst Evol Microbiol 53:569-576

Omondi MO, Xia X, Nahayo A, Liu XY, Korai PK, Pan GX (2016) Quantification of biochar effects on soil hydrological properties using meta-analysis of literature data. Geoderma 274:28-34

Oustriere N, Marchand L, Rosette G, Friesl-Hanl W, Mench M (2017) Wood-derived-biochar combined with compost or iron grit for in situ stabilization of $\mathrm{Cd}, \mathrm{Pb}$, and $\mathrm{Zn}$ in a contaminated soil. Environ Sci Pollut Res Int 24:7468-7481

Pandey V, Patel A, Patra DD (2016) Biochar ameliorates crop productivity, soil fertility, essential oil yield and aroma profiling in basil (Ocimum basilicum L.). Ecol Eng 90:361-366

Pandit PD, Gulhane MK, Khardenavis AA, Purohit HJ (2016) Mining of hemicellulose and lignin degrading genes from differentially enriched methane producing microbial community. Bioresour Technol 216:923-930

Pukall R, Lapidus A, Glavina Del Rio T, Copeland A, Tice H, Cheng JF, Lucas S, Chen F, Nolan M, Bruce D, Goodwin L, Pitluck S, Mavromatis K, Ivanova N, Ovchinnikova G, Pati A, Chen A, Palaniappan K, Land M, Hauser L, Chang YJ, Jeffries CD, Chain P, Meincke L, Sims D, Brettin T, Detter JC, Rohde M, Göker M, Bristow J, Eisen JA, Markowitz V, Kyrpides NC, Klenk H-P,
Hugenholtz P (2010) Complete genome sequence of Conexibacter woesei type strain (ID131577T). Stand Genomic Sci 2:212-219

Ramirez KS, Lauber CL, Knight R, Bradford MA, Fierer N (2010) Consistent effects of nitrogen fertilization on soil bacterial communities in contrasting systems. Ecology 91:3463-3470

Rogovska N, Laird D, Leandro L, Aller D (2017) Biochar effect on severity of soybean root disease caused by Fusarium virguliforme. Plant Soil 413:111-126

Sakai M, Hosoda A, Ogura K, Ikenaga M (2014) The growth of Steroidobacter agariperforans sp. nov., a novel agar-degrading bacteriumisolated from soil, is enhanced by the diffusible metabolites produced by the diffusible metabolites produced by bacteria belonging to Rhizobiales. Microbes Environ 29:89-95

Schiefner A, Angelov A, Liebl W, Skerra A (2016) Structural basis for cellulose binding by the type A carbohydrate-binding module 64 of Spirochaeta thermophila. Proteins 84:855-858

Schulz H, Dunst G, Glaser B (2013) Positive effects of composted biochar on plant growth and soil fertility. Agron Sustain Dev 33:817-827

Segata N, Izard J, Waldron L, Gevers D, Miropolsky L, Garrett WS, Huttenhower C (2011) Metagenomic biomarker discovery and explanation. Genome Biol 12:R60

Seki T, Matsumoto A, Shimada R, Inahashi Y, Ōmura S, Takahashi Y (2012) Conexibacter arvalis sp. nov., isolated from a cultivated field soil sample. Int J Syst Evol Microbiol 62:2400-2404

Song XZ, Zhou GM, Jiang H, Yu SQ, Fu JH, Li WZ, Wang WF, Ma $\mathrm{ZH}$, Peng CH (2011) Carbon sequestration by Chinese bamboo forests and their ecological benefits: assessment of potential, problems, and future challenges. Environ Rev 19:418-428

Steiner C, Das KC, Melear N, Lakly D (2010) Reducing nitrogen loss during poultry litter composting using biochar. J Environ Qual 39(4):1236-1242

Sun R, Zhang XX, Guo X, Wang D, Chu H (2015) Bacterial diversity in soils subjected to long-term chemical fertilization can be more stably maintained with the addition of livestock manure than wheat straw. Soil Biol Biochem 88:9-18

Taghizadeh-Toosi A, Clough TJ, Condron LM, Sherlock RR, Anderson CR, Craigie RA (2011) Biochar incorporation into pasture soil suppresses in situ nitrous oxide emissions from ruminant urine patches. J Environ Qual 40(2):468-476

Van Zwieten L, Kimber S, Morris S, Chan KY, Downie A, Rust J, Joseph S, Cowie A (2010) Effects of biochar from slow pyrolysis of papermill waste on agronomic performance and soil fertility. Plant Soil 327:235-246

Wu ZZ, Wang DJ, Li YQ, Du XH, Shao Q, Liu SH (2015) Effects of biochar fertilizer application on growth properties and photosynthetic and physiological characteristics of Pistacia chinensis Bunge. Ecol Environ Sci 24:992-997

Xie ZB, Xu YP, Liu G, Liu Q, Zhu JG, Tu C, Amonette JE, Cadisch $\mathrm{G}$, Yong JWH, Hu SJ (2013) Impact of biochar application on nitrogen nutrition of rice, greenhouse-gas emissions and soil organic carbon dynamics in two paddy soils of China. Plant Soil 370:527-540

Zhang AF, Bian RJ, Pan GX, Cui LQ, Hussain Q, Li LQ, Zheng JW, Zheng JF, Zhang XH, Han XJ, Yu XJ (2012) Effects of biochar amendment on soil quality, crop yield and greenhouse gas emission in a Chinese rice paddy: a field study of 2 consecutive rice growing cycles. Field Crops Res 127:153-160

Publisher's Note Springer Nature remains neutral with regard to jurisdictional claims in published maps and institutional affiliations. 